\title{
Export-Led Growth Hypothesis in Pakistan: A Reinvestigation Using the Bounds Test
}

\author{
Saima Siddiqui", Sameena Zehra*, Sadia Majeed ${ }^{* * * *}$, Muhammad \\ Sabihuddin Butt
}

\begin{abstract}
Trade is presumed to act as a catalyst to economic growth. This paper reinvestigates the export-led growth hypothesis in Pakistan by using annual time series data on exports, imports, terms of trade, and the labor force participation rate as explanatory variables and gross domestic product $(G D P)$ as the dependent variable for the period 1971-2005. The study uses the more comprehensive and recent bounds test or autoregressive distributed lag model (ARDL) proposed by Pesaran et al (2001) to examine the existence of short-run and long-run relationships between exports and economic growth, which is crucial in designing policy to enhance traderelated potential in Pakistan. The results indicate that exports, labor force, and imports have a positive effect on growth, while the terms of trade has a negative effect. The proxy for trade liberalization has a positive impact on economic growth. Finally, the chief finding of this study is that the hypothesis of export-led growth in the Pakistan economy is supported in both the short and long run. Economic growth in Pakistan is accompanied by fluctuations in exports and imports both in the short and long run, but the labor force participation rate has a negative effect only in the short run. The terms of trade has the same effect in the short and long run.
\end{abstract}

JEL Classification: C22, F49.

Keywords: Economic Growth, Exports, Imports, Labor Force Participation.

\section{Introduction}

Trade is presumed to act as a catalyst to economic growth in the sense that it can contribute to a more efficient allocation of resources

\footnotetext{
${ }^{*}{ }^{* *}$ MPhil fellow, Applied Economics Research Centre, University of Karachi.

${ }^{* * *}$ Assistant Professor, NED University \& MPhil fellow, Applied Economics Research Centre, University of Karachi.

**** Associate Professor \& Senior Research Economist, Applied Economics Research Centre, University of Karachi.
} 
within countries as well as transmit growth across countries and regions. Trade is a vehicle for the transmission of new ideas, technology, and managerial skills. The insight into the dynamic gains from trade is provided by a wide variety of theoretical models in the tradition of endogenous trade theories. The impact of trade policy, especially import substitution or export promotion, on growth and development has also been debated in the relevant literature. In the $1950 \mathrm{~s}$ and $1960 \mathrm{~s}$, most developing countries followed "import substitution policies" for economic growth, which stressed the need for less developed countries (LDCs) to evolve their own style of development and control their destiny by establishing domestically owned firms that could begin to produce for domestic consumption. Although it was recognized that, in all likelihood, there would be efficiency losses due to protection, the gains from increasing domestic production and movement down the cost curve would more than offset these inefficiencies.

Export-led growth is a term used loosely to refer to a strategy that encourages and supports the production of exports. The export-led growth hypothesis (ELGH) postulates that economic growth can be generated not only by increasing the amount of labor and capital within the economy, but also by expanding exports. In fact, exports are generally supposed to contribute positively to economic growth through different means: (i) facilitating the exploitation of economies of scale, (ii) relieving the foreign exchange constraint, (iii) enhancing efficiency through increased competition, and (iv) promoting the diffusion of technical knowledge ${ }^{1}$. Moreover, the growth of exports plays a major part in the growth process as it relieves a country from its balance of payment constraint by stimulating demand, encouraging savings, and capital accumulation. Exports increase the supply potential of the economy by raising the capacity to import. Hence, exports and export policies in particular are regarded as crucial growth stimulators.

Theoretical advances in the trade and growth literature have been complemented by the growing body of empirical literature that has sought to test the export-led growth hypothesis but produced results that were mixed/questionable. The theoretical agreement on export-led growth emerged among neo-classical economists after the successful story of newly industrialized countries (NICs). NICs have been successful in achieving high and sustainable rates of economic growth because of their free market- and outward-oriented economies. The foreign exchange earned from exports allows imports of capital and other intermediate goods, which increases

${ }^{1}$ For more detail see (Helpman and Krugman, 1985), (McKinnon, 1964), (Krueger, 1980), (Grossman and Helpman, 1991). 
production potential. ${ }^{2}$ Emrey (1967) empirically proves that higher rates of export growth lead to higher rates of economic growth. Syron and Walsh (1968) support the hypothesis but produce results that are sensitive, depending on the type of country under scrutiny, i.e., LDCs or developed countries. Serven (1968) supports the export-led growth hypothesis.

In a cross-section analysis, Kravis (1970), Michaely (1977) Bhagwati (1978), and Heller and Porter (1978), among others, explore the relationship between exports and growth. Balassa (1978) and Krueger (1980) identify that exports increase total factor productivity because of their impact on economies of scale and other externalities. ${ }^{3}$ Colombatto (1990), using a sample of 70 countries, and Ahmed and Harnhirun (1996) reject the exportled growth hypothesis. Sheehey (1993) finds inconsistent evidence of higher productivity in the export sector compared with the nonexport sector. Bahmani, Oskooee, and Alse (1993) find that there is a long-run relationship between real exports and real output in LDCs. Lee and Cole (1994) and Sharma and Dhaka (1994) find a bidirectional relationship between exports and growth. Kwan and Kwok (1995) consider exports a production input. Paul and Chowdhury (1995) find evidence of causality running from exports to GDP growth. To some extent, cross-section empirical investigations can explain why growth differs across a wide spectrum of countries. However, the main criticism is directed at cross-country studies. ${ }^{4}$

In response to these criticisms, a number of more recent econometric studies in the area of export-led growth exist for LDCs using time-series data to investigate the causal relationship between exports and growth, principally by means of Granger-type causality tests. These include the following. Fajana (1979) working on Nigeria, supports the export-led growth hypothesis and suggests that it is due to changes in domestic investment resources. Chow (1987) and Jin (1995) reveal that there is strong bidirectional causality in most NICs. Sun and Shan (1998) show similar results for China. Hsiao (1987) uses time-series data and rejects the exportled growth hypothesis for most LDCs in the sample used. Darrat (1987), Oskooee et al (1991), and Greenway and Sapsford (1994) find some support in favor of the export-led growth hypothesis. Sengupta (1991) supports the export-led growth hypothesis, suggesting that exports have a positive externality effect on growth. Vanden Berg and Schmidt (1994), Luis and

\footnotetext{
${ }^{2}$ See Mckinnon (1964) and Chenery and Strout (1966).

${ }^{3}$ Such as technology transfer, improving skills of workers, improving managerial skills and increasing productive capacity of economy.

${ }^{4}$ (Shan and Sun, 1998), Cross sectional analysis ignore the shifts in the relationship between variables over time within a country, while export growth and economic growth is a long run phenomenon.
} 
Letelier Saavedra (1994), Dutt and Ghosh (1996), Islam (1998), Begum, Shamshad, and Shamsuddin (1998), and Pereira and Xu (2000) also find evidence to support the export-led growth hypothesis.

Some recent studies on Pakistan posit that output growth has a perverse effect on export growth ${ }^{5}$ and that countries can accelerate their economic growth by exporting manufactured goods produced with modern technologies. ${ }^{6}$ Dodaro (1993) and Ahmed et al (2000) fail to find any significant relationship in either direction for Pakistan. Oskooee and Alse (1993) present strong empirical support for a two-way causality between export growth and GDP growth in eight (including Pakistan) out of nine countries. Rana (1985), and Love and Chandra (2004) argue that exports contribute positively to economic growth. Anwar and Sampath (2000) reveal a unidirectional causality in the case of Pakistan. Kemal et al (2002) find no evidence of causation in the short run in either direction. However, they find strong support for long-run causality from exports to GDP for Pakistan. Muslehuddin (2004) examines the export-led growth hypothesis for the five largest economies in South Asia, i.e., India, Pakistan, Bangladesh, Sri Lanka, and Nepal. The study finds long-run equilibrium relationships among exports, imports, and output for Bangladesh and Pakistan.

Khan and Saqib (1993) and Ashfaque Khan, and Afia (1995) find a strong relationship between export performance and economic growth in Pakistan. Mutairi (1993) finds no support for the period 1959-91, while Khan et al (1995) find strong evidence of bidirectional causality between export growth and economic growth. Shirazi and Manap (2004) strongly support a long-run relationship among imports, exports, and output growth, and unidirectional causality from exports to output growth, but no significant causality between imports and export growth. Quddus and Saeed (2005) find one-way causality running from exports to economic growth in the long run, with estimates that also reveal that the growth rate of exports, total investment, and labor employed have a positive effect on the GDP growth rate.

In much of the literature, exports are seen as causing growth. In developing economies such as Pakistan, which has sufficient domestic resources, export expansion still relies on importing certain goods that are not produced in the domestic market but play a key role in the manufacturing of export-driven goods. Thus, Pakistan still needs to locate and import the necessary technology in order to hold a competitive

\footnotetext{
${ }^{5}$ Jung and Marshall (1985).

${ }^{6}$ Hameed, Chaudhary and Khan (2005).
} 
position. This implies that imports as well as exports play a vital role in economic growth. The theoretical argument is that export-orientation increases the openness of the economy and, by exposing it to foreign technology and foreign competition, provokes a rapid rate of technological progress. All in all, these authors suggest that countries with a higher export growth rate over an extended period tend to grow faster than others.

Reviewing the validity of the export-led growth hypothesis reveals mixed results due to differences in sample period and econometric techniques such as OLS, VAR, co-integration procedures, and the Granger causality framework. The OLS method is not adequate for studying causality or a co-integrated relationship, while the Engle-Granger residual based cointegration tests are inefficient and can lead to contradictory results, especially when there are more than two $\mathrm{I}(1)$ variables under consideration (Pesaran and Pesaran, 1997). Johansen (1988, 1991) and Johansen and Juselius (1990) use tests for the multivariate case but the above methods require that the variables in the system be of equal order of integration. These methods do not include information on structural breaks in time series data, suffer from low power, and do not have good small sample properties. Due to these problems associated with the standard test methods, the OLS-based ARDL approach to co-integration has become popular in recent years.

The motive of this paper is to test the validity of long-term and short-term linkages for export-led growth in Pakistan, using the recent and more comprehensive bounds test or ARDL proposed by Pesaran et al (2001). The study employs annual time series data (for 1971-2006) along multiple structural breaks because structural changes can change the sources of growth, and affect the export-growth relationship.

The structure of this article is as follows: Section 2 presents the model, methods used to estimate variables, data, sources of data, and the definition of variables included in the model. Section 3 presents the estimated results. The last section summarizes the main results along with concluding remarks.

\section{Model Specification and Estimation Technique}

In examining the export-led growth hypothesis, we have employed the ARDL bounds test approach to co-integration analysis. The ARDL modeling approach popularized by Pesaran and Pesaran (1997), Pesaran and Smith (1998), Pesaran and Shin (1999), and Pesaran et al. (2001) has numerous advantages. The main advantage is that it can be applied 
regardless of the stationary properties of variables in the sample. The model allows a sufficient number of lags to capture the data generating process in a general-to-specific modeling framework (Laurenceson and Chai 2003, p. 28). Moreover, a dynamic error correction model (ECM) can be derived from ARDL through a simple linear transformation (Banerjee et al 1993, p. 51), which allows for inferences of long-run estimates, which is not possible under alternative co-integration procedures (Sezgin and Yildirim 2002). The ARDL method has the additional advantage of yielding consistent estimates of long-run parameters that are asymptotically normal, irrespective of whether the variables are $\mathrm{I}(0), \mathrm{I}(1)$ or mutually integrated. While it is not necessary to pretest the unit root, doing so complements the estimation process to ensure that none of the variables are integrated of higher order i.e., I(2). Moreover, unit root tests yield different conclusions, not only due to their different power, but also due to the different lag length selected in each test.

It also shows that appropriate lags in the ARDL are corrected for both residual correlation and endogenity. As long as the ARDL model is free of residual correlation, endogeneity is less of a problem (Pesaran and Shin 1999). The important advantage of ARDL against the single equation cointegration analysis such as that used by Engle and Granger (1987) is that the latter suffers from problems of endogeneity while the ARDL method can distinguish between dependent and explanatory variables. Indeed, one of the important advantages of the ARDL procedure is that estimation is possible even when explanatory variables are endogenous (Alam and Quazi, 2003). Hence, the ARDL model provides robust results for small sample sizes.

In view of the above, we construct the following mode1:

$$
\mathrm{GDP}=\beta_{0}+\beta_{1} \mathrm{X}+\beta_{2} \mathrm{M}+\beta_{3} \mathrm{TOT}+\beta_{4} \mathrm{LF}+\mathbf{u}
$$

Where $\beta$ 's are parameters, $\mathbf{u}$ is the error term and independent variables include $\mathrm{X}, \mathrm{M}$, TOT, and LF. The dependent variable is real GDP. For the above equation the unrestricted error correction version of the ARDL mode1 is given by:

$$
\begin{aligned}
& \Delta \mathrm{GDP}_{\mathrm{t}}=\beta_{0}+\beta_{1} \mathrm{GDP}_{\mathrm{t}-1}+\beta_{2} \mathrm{X}_{\mathrm{t}-1}+\beta_{3} \mathrm{M}_{\mathrm{t}-1}+\beta_{4} \mathrm{TOT}_{\mathrm{t}-1}+\beta_{5} \mathrm{LF}_{\mathrm{t}-1}+\sum_{i=1}^{m} \beta_{6} \Delta \mathrm{GDP}_{\mathrm{t}-\mathrm{i}} \\
& +\sum_{i=0}^{m} \beta_{7} \Delta \mathrm{X}_{\mathrm{t}-\mathrm{i}}+\sum_{i=0}^{m} \beta_{8} \Delta \mathrm{M}_{\mathrm{t}-\mathrm{i}}+\sum_{i=0}^{m} \beta_{8} \Delta \mathrm{TOT}_{\mathrm{t}-\mathrm{i}}+\sum_{i=0}^{m} \beta_{9} \Delta \mathrm{LF}_{\mathrm{t}-\mathrm{i}}+\mathrm{u}
\end{aligned}
$$


The first part of the above equation represents the long-run dynamics of the model while the second part shows the short-run relationship, in which $\Delta$ is the first difference operator, $u_{t}$ is a white noise disturbance term, and all variables are expressed in natural logarithms. The equation indicates that economic growth, in terms of real GDP, tends to be influenced by its past values so that it involves other disturbances or shocks. Therefore, Equation 2 was modified to capture and absorb certain economic shocks. Dummy variables (DUM) with a value of 0 before and a value of 1 after the trade liberalization period have been included in the equation to measure the impact of structural breaks in the economy.

$$
\begin{aligned}
& \Delta \mathrm{GDP}_{\mathrm{t}}=\beta_{0}+\beta_{1} \mathrm{GDP}_{\mathrm{t}-1}+\beta_{2} \mathrm{X}_{\mathrm{t}-1}+\beta_{3} \mathrm{M}_{\mathrm{t}-1}+\beta_{4} \mathrm{TOT}_{\mathrm{t}-1}+\beta_{5} \mathrm{LF}_{\mathrm{t}-1}+\gamma D U \mathrm{M}_{\mathrm{t}}+ \\
& \sum_{i=1}^{m} \beta_{6} \Delta \mathrm{GDP}_{\mathrm{t}-\mathrm{i}}+\sum_{i=0}^{m} \beta_{7} \Delta \mathrm{X}_{\mathrm{t}-\mathrm{i}}+\sum_{i=0}^{m} \beta_{8} \Delta \mathrm{M}_{\mathrm{t}-\mathrm{i}}+\sum_{i=0}^{m} \beta_{8} \Delta \mathrm{TOT}_{\mathrm{t}-\mathrm{i}}+\sum_{i=0}^{m} \beta_{9} \Delta \mathrm{LF}_{\mathrm{t}-\mathrm{i}}+\mathrm{u}
\end{aligned}
$$

The ARDL approach involves two steps for estimating the long-run relationship (Pesaran et al., 2001). The first step is to examine the existence of a long-run relationship among all variables in the equations being estimated. The second step is to estimate the long- and short-run coefficients of the same equation. We run the second step only if we find a long-run relationship in the first step. Thus, to test the long-run relationship in Equation 3, we impose restrictions on the estimated long-run coefficients of the variables. The null and alternative hypotheses are as follows:

$$
\begin{aligned}
& \mathbf{H}_{\mathbf{0}}: \beta_{1}=\beta_{2}=\beta_{3}=\beta_{4}=\beta_{5}=0 \text { (no long-run relationship) } \\
& \mathbf{H}_{\mathbf{1}}: \beta_{1} \neq \beta_{2} \neq \beta_{3} \neq \beta_{4} \neq \beta_{5} \neq 0 \text { (long-run relationship exists) }
\end{aligned}
$$

The calculated F-statistic in this procedure has a nonstandard distribution, and is compared with two sets of critical values tabulated by Pesaran et a1. (2001) i.e., to conduct bounds testing for the above equation. If the calculated F-statistic is larger than the upper bound critical value, then the null hypothesis of no co-integration is rejected irrespective of whether the variables are $\mathrm{I}(0)$ or $\mathrm{I}(1)$. If it is below the lower bound, then the null hypothesis of no co-integration cannot be rejected. If it falls inside the critical value band, the test is inconclusive. When one set assumes that all variables are $I(0)$, the decision is based on the lower bound; when the other set assumes they are I(I), then decision is based on the upper bound.

Once co-integration is established, a lag length is selected for each variable. The ARDL method estimates $(\mathbf{p}+\mathbf{1})^{\mathbf{k}}$ number of regressions in order 
to obtain the optimal lag length for each variable, where $p$ is the maximum number of lags used and $\mathrm{k}$ is the number of variables in the equation. The model can be selected using model selection criteria such the SchwartzBayesian criteria (SBC) or Akaike's information criteria (AIC). The AIC-based model is selected here as it has a lower prediction error than that of the SBC-based model. ${ }^{7}$

In the second step, the long-run relationship is estimated using the selected ARDL model. When there is a long-run relationship between variables, there exists an error correction representation. Therefore, in the third step, the error correction model is estimated. The error correction model result indicates the speed of adjustment back to the long-run equilibrium after a short-run shock. A general error correction representation of Equation (3) is given below. (In Section III Table-5).

To ascertain the goodness of fit for the ARDL mode1, we conduct a diagnostic test and stability. The diagnostic test examines the serial correlation, functional form, normality, and heteroscedasticity associated with the model. The structural stability test is conducted by employing the cumulative sum of recursive residuals (CUSUM) and the cumulative sum of squares of recursive residuals (CUSUMSQ). Examining the prediction error of the model is another way of ascertaining the reliability of the ARDL mode1. If the error or the difference between the real observation and the forecast is infinitesimal, then the model can be regarded as best fitting.

\section{Data Analysis}

The variables involved in this study are real GDP, real exports, real imports, labor force participation rate, and terms of trade series. Growth of exports and reduction in imports plays a major part in the growth process as it relieves a country from the balance of payment constraint by stimulating demand, encouraging savings, and capital accumulation. The terms of trade have an important bearing on export earnings and income that has been neglected in many studies. The purpose of using the labor force participation rate is to capture its role in the economy (Pakistan being a labor-intensive country) and drawing attention to the point that an adequate supply of skilled labor leads to a higher level of economic growth.

The data for variables such as GDP, exports, imports, terms of trade, and labor force participation rate were obtained from the Economic Survey of Pakistan. We use are annual time series data from 1971 to 2005. All the

\footnotetext{
${ }^{7}$ Damodar N. Gujrati, $7^{\text {th }}$ Edition
} 
dependent and explanatory variables except for labor were deflated by the consumer price index (CPI), whereby the year 1999/2000 was treated as the base year $(99 / 00=100)$. Furthermore, all the series' were transformed into $\log$ form. Log transformation can reduce the problem of heteroscedasticity because it compresses the scale in which the variables are measured, thereby reducing a tenfold difference between two values to a twofold difference (Gujarati 1995).

\section{Estimation Results}

A unit root test is performed to ensure that none of the variables in equation (1) are integrated of the order I(2) or higher; this would render the procedure inapplicable. Augmented Dickey-Fuller (ADF) unit root test results are reported in Table-1. The order of autoregressive lags (n) is selected such that it produces non auto-correlated OLS residuals.

Table-1: Unit Root Estimation

\begin{tabular}{lccccc}
\hline \multicolumn{1}{c}{ Variables } & \multicolumn{2}{c}{ Level } & & \multicolumn{2}{c}{ First Difference } \\
\cline { 2 - 3 } & $\begin{array}{c}\text { Intercept } \\
\text { and Trend }\end{array}$ & $\begin{array}{c}\text { No. of } \\
\text { Lags }\end{array}$ & & $\begin{array}{c}\text { Intercept } \\
\text { and Trend }\end{array}$ & $\begin{array}{c}\text { No. of } \\
\text { Lags }\end{array}$ \\
\hline Real GDP & -2.701049 & 1 & $-4.720575^{*}$ & 1 \\
Real Export & -3.191203 & 1 & $-4.652737^{*}$ & 1 \\
Real Import & $-3.777174^{* *}$ & 1 & -4.648103 & 1 \\
Terms of Trade & -2.943283 & 1 & $-6.010386^{*}$ & 1 \\
Labor Force par. Rate & -0.586527 & 1 & $-3.280599^{* * *}$ & 1
\end{tabular}

Note: *, **, *** represents the level of significance at $1 \%, 5 \%, 10 \%$ respectively with critical values of $-4.2605,-3.5514,-3.2081$ with intercept and trend at level while -4.2712 , $-3.5562,-3.2109$ are the critical values with intercept and trend at first difference.

Since the results presented in Table- 1 show that the variables are integrated of mixed order i.e., 1 or lower, we can apply the ARDL method to our model. The above table shows that real GDP, real exports, terms of trade, and labor force participation rate are stationary at $\mathrm{I}(1)$ and real imports is stationary at the level i.e., I(0).

The first step of of ARDL procedure is to estimate equation (3) and test for the presence of long-run relationship (co-integration) among the variables of Equation (1). Bahmani- Oskooee and Bohal (2000) have shown that the results of this first step are sensitive to lag length $(\mathrm{m})$, selected in equation (2). Since we are using annual data, a shorter lag length is 
considered. We estimate Equation (2) by varying lag length $(\mathrm{m})$ from 0 to 2 and compute the F-statistic for the joint significance of lagged levels of variables. The computed F-statistic for each order of lags is given below in Table-2.

Table-2: Lag Length Selection

\begin{tabular}{cl}
\hline Lag Order & \multicolumn{1}{c}{ F- Statistics } \\
\hline 0 & $\mathrm{~F}(5,23)=2.24$ \\
1 & $\mathrm{~F}(5,18)=3.51$ \\
2 & $\mathrm{~F}(5,13)=10.33^{*}$ \\
\hline
\end{tabular}

Note: The relevant critical value bounds for F-statistics (an unrestricted intercept and no trend) are taken from tables C1.iii in Pesaran et a1. (2001). At the 99\% level, the critical value bounds for F-statistics are 5.15-6.36. * indicates that the computed statistic falls above the upper bound value.

Table-2 shows that test results vary with the order of lags in the mode1. When the order of lags in equation (3) is 2, the computed F-statistic 10.33 is above their upper bounds 6.36 and the null hypothesis of no cointegration among the variables in equation (1) is strongly rejected at a $1 \%$ significance level. Thus, there exists a long-run relationship among the variables in equation (1) and the total number of regressions estimated following the ARDL method in Equation (3) is $(2+1)^{5}=243$.

We can now proceed to the second stage of estimation. In the next stage, we select the optimal lag length for the ARDL model to determine its long-run coefficients. With the maximum order of lag set to 2, lag selection criteria AIC was used to select the appropriate order for the ARDL model. The long-run results presented in Table-3 indicate that that exports, imports, and labor force are positively correlated and terms of trade negatively correlated with economic growth. 
Table-3: Long-Run Estimates of Model Based on Equation 3 (Dependent Variable GDP)

\begin{tabular}{|c|c|c|c|}
\hline Variable & Coefficient & t-Statistic & Prob. \\
\hline $\mathrm{C}$ & 1.2565 & 0.3449 & 0.7403 \\
\hline $\mathrm{D}(\mathrm{GDP}(-1))$ & -1.9668 & -2.9558 & 0.0212 \\
\hline $\mathrm{D}(\mathrm{GDP}(-2))$ & -0.6827 & -2.0480 & 0.0798 \\
\hline $\mathrm{D}(\mathrm{GDP}(-3))$ & -0.8450 & -2.3373 & 0.0521 \\
\hline $\mathrm{D}(\mathrm{X})$ & -0.2632 & -2.5473 & 0.0165 \\
\hline $\mathrm{D}(\mathrm{X}(-1))$ & 0.7661 & 3.2739 & 0.0136 \\
\hline $\mathrm{D}(\mathrm{X}(-2))$ & 0.3598 & 2.1449 & 0.0691 \\
\hline $\mathrm{D}(\mathrm{M})$ & -0.0240 & -1.3873 & 0.1071 \\
\hline $\mathrm{D}(\mathrm{M}(-1))$ & 0.0402 & 1.7027 & 0.0960 \\
\hline $\mathrm{D}(\mathrm{M}(-2))$ & 0.0324 & 1.8320 & 0.0927 \\
\hline $\mathrm{D}(\mathrm{TOT})$ & -0.0801 & -1.8776 & 0.0875 \\
\hline D(TOT(-1)) & -0.6094 & -2.6798 & 0.0316 \\
\hline D(TOT(-2)) & -0.2016 & -1.5906 & 0.1157 \\
\hline $\mathrm{D}(\mathrm{LF})$ & -2.8499 & -2.5573 & 0.0377 \\
\hline $\mathrm{D}(\mathrm{LF}(-1))$ & 0.1930 & 0.2101 & 0.8396 \\
\hline $\mathrm{D}(\mathrm{LF}(-2))$ & 0.4283 & 0.5065 & 0.6280 \\
\hline DUM & 0.1057 & 1.8168 & 0.1121 \\
\hline $\mathrm{GD}(-1)$ & 1.1456 & 2.3592 & 0.0504 \\
\hline$X(-1)$ & -1.8629 & -2.8939 & 0.0204 \\
\hline $\mathrm{M}(-1)$ & -0.1219 & -2.0118 & 0.0734 \\
\hline TOT(-1) & 0.0851 & 1.3845 & 0.1056 \\
\hline $\mathrm{LF}(-1)$ & -1.7515 & -1.7572 & 0.1193 \\
\hline R-squared & 0.938827 & AIC & -3.611510 \\
\hline Adjusted $\mathrm{R}^{2}$ & 0.755309 & F-statistic & 3.45152 \\
\hline S.E. of regression & 0.037907 & Prob(F-stat) & 0.04660 \\
\hline SBC & -2.574251 & Durbin-Watson & 2.075719 \\
\hline
\end{tabular}

Based on the estimate for the unrestricted error correction model of ARDL, the long-run elasticities are the coefficient of the one lagged explanatory variable (multiplied by a negative sign) divided by the coefficient of the one lagged dependent variable (Bardsen, 1989). For example, in Equation (3), the long-run export and import elasticities are $\left(\beta_{2} / \beta_{1)}\right.$ and $(\beta 3 / \beta 1)$, respectively (Table- 4$)$. 
Table-4: Long-Run Estimated Coefficients

\begin{tabular}{ll}
\hline Variable & Coefficient \\
\hline $\mathrm{X}$ & 1.6260 \\
$\mathrm{M}$ & 0.1604 \\
TOT & -0.0743 \\
LF & 1.5289 \\
DUM & 0.1057 \\
\hline
\end{tabular}

The most significant factor in determining economic growth in Pakistan is exports (X), which, with an estimated elasticity of 1.626, shows that, in the long run, a $1 \%$ increase in the $\mathrm{X}$ leads to a $1.626 \%$ increase in economic growth. The next-most important factor in determining economic growth is the labor force participation rate: the coefficient of LF is 1.528 and statistically significant showing that, in the long run, a $1 \%$ increase in $\mathrm{LF}$ leads to a $1.528 \%$ increase in economic growth. The coefficient of imports (M) is 0.16044 , suggesting that, in the long run, a $1 \%$ increase in $M$ leads to a $0.16044 \%$ increase in economic growth; this shows that import goods might comprise nonconsumption items.

Interestingly, we find that the coefficient of terms of trade is inconsistent with the previous study (Jim and Chandra). Theoretically, if the Pakistani rupee depreciates (i.e., the Rs/US\$ increases in value), this will raise the competitiveness of domestic commodities, and hence encourage exports. By the same token, appreciation of the rupee is expected to deter exports. The findings of this study, however, show a negative relationship $(-0.074)$ between these two variables, which means that the $1 \%$ increase in terms of trade will slow down economic growth by $0.074 \%$ on average. The estimated coefficient of the dummy variable shows that trade liberalization has a significant positive impact on economic growth.

Short-run effects are captured by the coefficients of the firstdifferenced variables in Equation (3). Next, we examine the short-run dynamics of the model by estimating the ARDL error correction representation of Equation (3). Estimates of error correction representation of the ARDL model are given below in Table- 5 . 
Table-5: Short-Run Disequilibrium $\operatorname{Model}(2,1,1,1,1,1)$

(Dependent Variable $\Delta$ GDP)

\begin{tabular}{lccc}
\hline \multicolumn{1}{c}{ Variable } & Coefficient & t-Statistic & Prob. \\
\hline $\mathrm{C}$ & 0.0370 & 2.1864 & 0.0397 \\
$\Delta \mathrm{GDP}(-1)$ & 0.0537 & 0.2566 & 0.7999 \\
$\Delta(\mathrm{X})$ & 0.1738 & 2.1096 & 0.0465 \\
$\Delta(\mathrm{M})$ & 0.0535 & 1.6813 & 0.1068 \\
$\Delta$ (TOT) & -0.0553 & -0.7378 & 0.4684 \\
$\Delta(\mathrm{LF})$ & -0.1446 & -0.2448 & 0.8089 \\
DUM & 0.0069 & 0.4111 & 0.6850 \\
ECM(-1) & -0.3242 & -2.0501 & 0.0525 \\
R-squared & 0.484809 & AIC & -3.286385 \\
Adjusted R & 0.357248 & SBC & -2.912732 \\
S.E. of regression & 0.041848 & F-statistic & 1.251571 \\
Durbin-Watson & 1.790343 & Prob(F-statistic) & 0.318404 \\
\hline
\end{tabular}

An examination of the error correction model in Table-5 shows that export growth has the strongest effect on economic growth in the short run. The short-run effect of terms of trade on economic growth in Pakistan is weak and statistically insignificant at even a $10 \%$ significance level. The coefficient of the ECM term has the correct sign and is significant. It confirms a short-run relationship between the variables in equation (1). It suggests that the adjustment process is moderate. More than $32 \%$ of the previous year's disequilibrium in economic growth from its equilibrium path will be corrected in the current year. Thus, the evidence presented in this section suggests that economic growth in Pakistan is accompanied by fluctuations in exports and imports both in the short run and long run but that the labor force participation rate has a negative impact in the short run. Terms of trade have the same effect in both the short and long run.

\section{Stability and Diagnostic Test}

Next, we examine the stability of the short-run and long-run coefficients. Following Pesaran and Pesaran (1977), we use the Brown et al (1975) stability testing technique, also known as the cumulative (CUSUM) and cumulative sum of squares (CUSUMSQ) tests. The CUSUM and 
CUSUMSQ statistics are updated recursively and plotted against the break points. If the plotted points for the CUSUM and CUSUMSQ statistics stay within the critical bounds of a 5\% level of significance, the null hypotheses for all coefficients in the given regression are stable and cannot be rejected. The CUSUM and CUSUMSQ plotted points to check the stability of the short- and long-run coefficients in the ARDL error correction model (Table5) are given below in the figure. It shows that both statistics CUSUM and CUSUMSQ are within the critical bounds, indicating that all coefficients in the ARDL error correction model are stable.

Plot of Cumulative Sum of Recursive Residuals

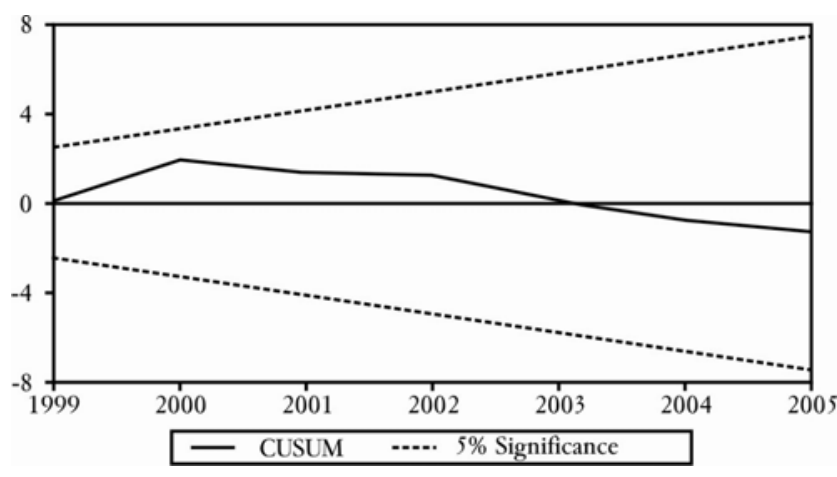

Plot of Cumulative Sum of Recursive Residuals

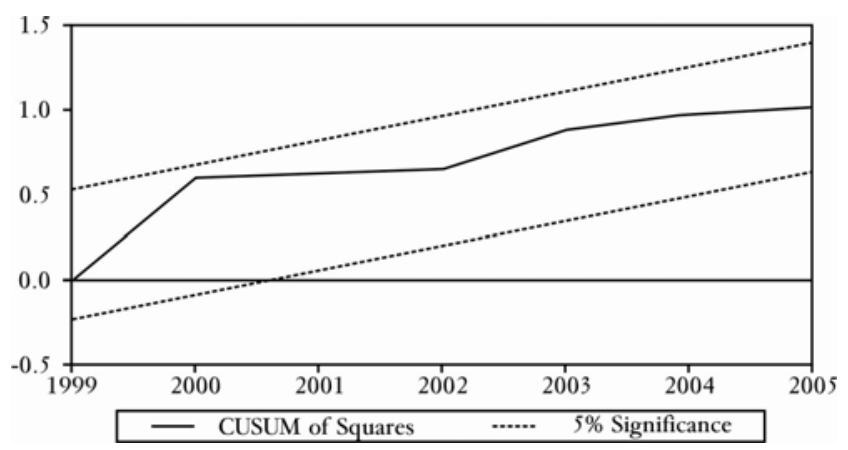

\section{Conclusion}

This study adopts a different perspective, i.e., to test the relationship between exports and output growth in the Pakistan economy using the newly proposed bounds testing approach. Following the lead of trade and development theory and the aggregate production function, we have developed a conceptual model that incorporates different channels via different variables that affect the relationship between exports and economic growth. Note that this study differs from others in that it considers other 
important macroeconomic determinants. The ARDL model indicates that exports, labor force, and imports have a positive impact on economic growth, while the terms of trade have a negative influence on growth. The proxy for trade liberalization affects economic growth positively.

Finally, a major finding of this study is that the hypothesis of exportled growth in the Pakistan economy is supported in both the short and long run. From these findings spring several policy recommendations. First, domestic economic performance is sensitive to changes in international markets. The government should therefore implement effective macroeconomic policies in stabilizing its trade balance and liberalizing the country's trade as well as attracting export-oriented foreign direct investment into the country. We suggest export diversification away from monofactor cotton. The government should also ensure an adequate supply of well-equipped labor, as this would lead to a higher level of economic growth. Finally, a stable terms of trade policy is essential in maintaining good economic performance, as its movements can have a negative impact on economic prosperity. 


\section{References}

Alam, M. Imam and Quazi, R. M., 2003, "Determinants of Capital Flight: An Econometric Case Study of Bangladesh.” International Review of Applied Economics, Vol. 17, 1.

Alse, J. and Bahmani-Oskooee, Moshe 1993, "Export Growth and Economic Growth: An Application of Co-Integration and Error-Correction Modeling." Journal of Developing Areas, Vol. 27 : 535-642.

A1-Yousif, Yousif Khalifa, 1997, "Exports and Economic Growth: Some Empirical Evidence from Arab Gulf Countries.” Applied Economics, Vol. 29 : 693-697.

Ahmed, J. and S. Harnhirun, 1996, "Co-Integration and Causality between Exports and Economic Growth: Evidence from the ASEAN Countries." Canadian Journal of Economics, Vo1. 24, Special Issue : 413-416.

Anwar, Muhammad S. and R. K. Sampath, 2000, "Exports and Economic Growth.” Indian Economic Journal, Vo1. 47, 3 : 79-88.

Balassa, B., 1978, "Exports and Economic Growth: Further Evidence." Journal of Development Economics, Vo1. 5 : 181-189.

McCabe, B. P. M. and Harrison, M. J., 1980, "Testing the Constancy of Regression Relationships over Time Using Least Squares Residuals.” Applied Statistics, Vo1. 29, 2 : 142-148.

Balassa, Bela, 1984, "Exports, Policy Choices and Economic Growth in Developing Countries after the 1973 Oil Shock." World Development.

Bahmani-Oskooee, Mohsen and Alse, Janardan, 1993, "Export Growth and Economic Growth: An Application of Co-Integration and ErrorCorrection Modelling." Journal of Development Areas, Vo1. 27 : 535 42.

Bahmani-Oskooee, M. and Boh1, M. T., 2000, "German Monetary Unification and the Stability of the German M3 Money Demand Function.” Economics Letters, Vo1. 66 : 203-208. 
Bahmani-Oskooee, Mohsen, Mohtadi, Hamid and Ghiath Shabsigh, 1991, "Exports, Growth and Causality in LDCs: A Re-Examination." Journal of Development Economics, Vo1. 36 : 405-15.

Banerjee, Anindya, Dolado, Juan J., Galbraith, John W. and David F. Hendry, 1993, Co-Integration, Error Correction and the Econometric Analysis of Non Stationary Data. Oxford University Press.

Bardsen, G. 1989, "Estimation of Long Run Coefficients in Error Correction Models." Oxford Bulletin of Economics and Statistics, Vol. 51, 3 : 345-50.

Begum, S. and Shamsuddin, A. F. M., 1998, "Exports and Economic Growth in Bangladesh." Journal of Development Studies, Vo1. 35, 1 : 89-114.

Bhagwati, J. 1978, Anatomy and Consequences of Exchange Control Regimes: Liberalization Attempts and Consequences. Cambridge, MA: Ballinger.

Chenery, H. B. and Chu, O., 1996, "U.S Export and Economic Growth Causality.” Atlantic Economic Journal, Vol. 24 : 263.

Chow, P. C. Y., 1987, "Causality between Export Growth and Industrial Development: Empirical Evidence from the NICs." Journal of Development Economics, Vo1. 26, 1 : 55-63.

Colombatto, E.,1990, “An Analysis of Exports and Growth.” Kyklos, Vo1. 43, $4: 579-97$

Dickey, D. A. and Fuller, W. A., 1979, Distribution of the Estimators for Autoregressive Time Series with a Unit Root." Journal of the American Statistical Association, Vo1. 74 : 427-31.

Darrat, A. F., 1987, "Are Exports an Engine of Growth? Another Look at the Evidence." Applied Economics, Vol. 19, 2 : 277-83.

Dodaro, S., 1993, "Exports and Growth: A Reconsideration of Causality." Journal of Developing Areas, Vo1. 27 : 227-244.

Dutt, Swarna D. and Ghosh, Dipak, 1996, "The Export Growth - Economic Growth Nexus: A Causality Analysis.” The Journal of Developing Areas, Vo1. 30 : 167-182. 
Emery, R., 1967, “The Relation of Export and Economic Growth." Kyklos Vol. $20: 4$.

Engle, R., and Granger, C., 1987, "Co-Integration and Error Correction Representation, Test and Telling." Econometrica, Vo1. 55, 2 : 251276.

Fajana, O., 1979, “Trade and Growth: The Nigerian Experience." World Development, Vol. 7 : 73-8

Feder, G., 1983, “On Exports and Economic Growth.” Journal of Development Economics, Vo1. 12 : 59-73.

Ghatak, S., and Price, S. W., 1997, "Export Composition and Economic Growth: Co-Integration and Causality Evidence for India.” Review of World Economics, Vo1. 133 : 538-553.

Government of Pakistan, 2005, Economic Survey of Pakistan, 1977-2005, Government of Pakistan, Finance Division, Islamabad.

Greenway, D. and D. Sapsford, 1994, "Exports, Growth and Liberalization: An Evaluation.” Journal of Policy Modeling, Vol. 16, 2 : 165-186.

Grossman, G.M. and E. Helpman, 1990, “Comparative Advantage and Long Run Growth.” American Economic Review, Vol. 80 : 796-815.

Gujarati, D. N. 1995, Basic Econometrics, 3rd and 7th Ed., New York: McGraw Hill.

Heller, P. S. and Porter, R. C., 1978, "Export and Growth: An Empirical Reinvestigation.” Journal of Dvelopment Economics, Vo1. 5 : 191-3.

Helpman, E. and Krugman, P. R., 1985, Market Structure and Foreign Trade. Cambridge (Mass) MIT Press.

Hsiao, M. W., 1987, "Test of Causality and Exogenity between Export and Economic Growth: The Case of Asian NICs.” Journal of Economic Development, Vol. 12 : 143-159.

Islam, M. N., 1998, "Exports Expansion and Economic Growth: Testing for Co-Integration and Causality.” Applied Economics, Vol. 30, 3 : 41525 . 
Jin, J. C., 2002, "Exports and Growth: Is the Export-Led Growth Valid for Provincial Economies?” Applied Economics, Vo1. 34 : 203-215.

Jinjun, Xue., 1995, "The Export-Led Growth Model and its Application to China." Hitotsubashi Journal of Economics, Vol. 36 : 189-206.

Johannsen, S. 1988, "Statistical Analysis of Cointegration Vectors," Journal of Economic Dynamics and Control, Vol. 12, 6 : 231-254.

Johansen, S. and K. Juselius, 1990, "Maximum Likelihood Estimation and Inference on Co-Integration with Application for the Demand for Money." Oxford Bulletin of Economics and Statistics, Vo1. 52: 169210.

Jung, W.S. and P.J. Marsha11, 1985, "Exports, Growth and Causality in Developing Countries.” Journal of Development Economics, Vol. 18, 1-12.

Kravis, I. B., 1970, "Trade as a Handmaiden of Growth: Similarities between the Nineteenth and Twentieth Centuries.” Economic Journal, Vol. $80,3: 850-872$

Krueger, A. O., 1978, Foreign Trade Regimes and Economic Development: Liberalization Attempts and Consequences, Cambridge, MA: Ballinger.

Kwan, A. and B. Kwok, 1995, "Exogeneity and the Export-Led Growth Hypothesis: The Case of China." Southern Economic Journal, Vol. $61,8: 1158-1166$.

Keong, Yusop and Sen, Khim, 2005, "Export-Led Growth Hypothesis in Malaysia: An Investigation using Bounds Test.” Sunway Academic Journal, Vol. 2 : 13-2.

Kemal, A. R., Musleh ud Din, Usman Qadir, Lloyd, F. and Sirimevan, S. Colombage, 2002, "Exports and Economic Growth in South Asia." A Study Prepared for the South Asia Network of Economic Research Institutions.

Khan, A and Afia, 1995, "Export Growth and Causality: An Application of Co-Integration and ECM Model." The Pakistan Development Review, Vol. 3. 
Khan, A. H. and N. Saqib, 1993, "Exports and Economic Growth: The Pakistan Experience." International Economic Journal, Vol. 7, 3 : 53-64.

Khan, A. H., A. Malik, and L. Hassan, 1995, "Exports, Growth and Causality: An Application of Co-Integration and Error-Correction Modeling." Paper presented at the Eleventh Annual General Meeting of the Pakistan Society of Development Economists. April 18-21. PIDE, Islamabad.

Love, Jim and Chandra, Ramesh, 2005, “Testing Export-Led Growth in South Asia." Journal of Economic Studies, Vol. 32, 2 : 132-145.

Laurenceson, James and Joseph C.H. Chai, 2003, Financial Reform and Economic Growth in China. Cheltenham, UK, Edward Elgar.

Lee, F and Cole, W., 1994, "Simultaneity in the Study of Exports and Economic Growth.” International Economic Journa1, Vo1. 8, 2 : 3341.

Luis F., Letelier Saavedra L., 1994,” Exportaciones, Orientación al Comercio y Crecimiento: Un Enfoque de Cointegración." Latin American Journal of Economics, Vol. 94 : 99-120.

McKinnon, R., 1964, "Foreign Exchange Constraint in Economic Development and Efficient Aid Allocation”, Economic Journal, Vol. 74 : 388-409.

Michaely, M., 1977, "Exports and Growth: An Empirical Investigation." Journal of Development Economics, Vo1. 4, 1 : 49-53.

Musleh ud Din, 2004, "Exports, Imports, and Economic Growth in South Asia: Evidence Using a Multivariate Time-Series Framework." The Pakistan Development Review, Vo1. 43, 2 : 105-124.

Mutairi, Naief A1-., 1993, "Exports and Pakistan's Economic Development.” Pakistan Economic and Social Review, Vo1. 31, 2 : 134-146.

Pau1, S. and Chowdhury K., 1995, "Export-Led Growth Hypothesis: Some Empirical Testing.” Applied Economics Letters, Vo1. 2, 6 : 177-179.

Pereira, Alfredo M. and Xu, "Zhenhui Export Growth and Domestic Performance." The Review of Economic Studies, Vo1. 67, 1. 
Pesaran, M. H., Y. Shin, and R. J. Smith, 1997, “Testing for the Existence of a Long-Run Relationship." DAE Working Paper No. 9622, Department of Applied Economics, University of Cambridge.

Pesaran, M. H., Y. Shin, and R. J. Smith, 1999, "Bounds Testing Approaches to the Analysis of Long-Run Relationships," DAE Working Paper No. 9907, Department of Applied Economics, University of Cambridge.

Pesaran, H. M., Shin, Y., Smith, R. J., 2001, "Bounds Testing Approaches to the Analysis of Long-Run Relationships." Journal of Applied Econometrics, Vol. 16 : 289-326.

Quddus, Muhammad A. and Ikram Saeed, 2005, "An Analysis of Export and Growth in Pakistan.” The Pakistan Development Review, Vol. 44, 4 : 921-937.

Rana, Pradumna B., 1985, "Exports and Economic Growth in the Asian Region.” ADB Economic Staff Paper No. 25.

Sezing, S. and Yildirim, J., 2002, "The Demand for Turkish Defence Expenditure." Defence and Peace Economics, Vo1. 13, 2 : 121-128.

Sengupta, J. K., 1991, "Rapid Growth in NICs in Asia: Tests of the New Growth Theory for Korea.” Kyklos, Vo1. 44, 4 : 561-579.

Serven, A. K., 1968, "The Relation of Exports and Economic Growth: Comment.” Kyklos, Vol. 21, 3 : 546-48.

Shan, J. and Sun F., 1998, "On the Export-Led Growth Hypothesis: The Econometric Evidence from China." Applied Economics, Vol. 30 : 1055-65.

Sharma, U. C. and D. Dhaka1., 1994, "Causal Analysis between Exports and Economic Growth in Developing Countries.” Applied Economics, Vol. 26 : 1145-1157.

Sheehey, Edmund J., 1993, "Exports and Growth: Additional Evidence." Journal of Development Studies, Vo1. 28, 4.

Shirazi, Nasim Shah and Manap, Turkhan Ali Abdul, 2004, "Export-Led Growth Hypothesis: Further Econometric Evidence from South Asia." The Developing Economies, Vo1. 43, 4 : 472-488. 
Syron, R. F. and B. M. Walsh, 1968, "The Relation of Exports and Economic Growth: A Note." Kyklos, Vo1. 21, 3 : 541-545.

Tyler, W. G., 1981, "Growth and Export Expansion in Developing Countries: Some Empirical Evidence." Journal of Development Economics, Vol. 9 : 121-130.

Todaro, P. and Smith, S. C, 2003, Economic Development, Eighth Edition, Addison Wesley, Singapore.

Van den Berg, H. and Schmidt, J.R., 1994, "Foreign Trade and Economic Growth: Time Series Evidence from Latin America." Journal of International Trade and Economic Development, Vol. 3 : 249-68. 